\title{
Методичний підхід до оцінювання рівня загроз цивільному населенню у разі застосування стрілецької зброї по безпілотних літальних апаратах
}

\section{Володимир Мірненко ${ }^{\text {; }}$ Сергій Новіченко ${ }^{\mathrm{B}}$ Олександр Доска; Павло Опенько ; Олександр Авраменко}

\author{
Received: April 1, 2020 | Revised: April 21, 2020 | Accepted: April 30, 2020
}

DOI: $10.33445 /$ sds.2020.10.2.5

\begin{abstract}
Анотація
Результати досліджень, що опубліковано в статті, будуть корисні для керівників військових колективів всіх рівнів, які відповідають за забезпечення безпеки цивільного населення в ході застосування зброї. В статті розглядаються методичний підхід щодо оцінювання рівня загроз цивільному населенню у разі застосування стрілецької зброї по безпілотним літальним апаратам (БпЛА). Проаналізовані існуючі документи, які регламентують застосування стрілецької зброї, встановлено, що питання безпеки цивільного населення при виконанні стрільб по повітряних цілях в них не розглядалося, що дозволило визначити невирішене наукове завдання, що полягає в формуванні методичного підходу до оцінювання рівня загроз цивільному населенню у разі застосування стрілецької зброї по БпЛА. Запропоновано наукове обґрунтування визначення ймовірності випадкового влучання кулі в людину, що розташована на певній відстані від стрілка при стрільбі по БпЛА. В якості показника оцінки рівня загроз цивільному населенню при застосуванні стрілецької зброї по БпЛА обґрунтовано використання показника “ймовірність випадкового влучення кулі в людину". Наведений методичний підхід до оцінювання загроз цивільному населенню, який ґрунтується на імітаційному моделюванні процесу польоту кулі у вертикальній площині, основою якого $\epsilon$ алгоритм визначення ймовірності випадкового влучення кулі в людину, який дозволяє, в залежності від кінетичної енергії кулі, розрахувати імовірність випадкового вбивства та імовірність випадкового поранення людини. Представлені розрахункові співвідношення, які дозволяють в залежності від кінетичній енергії кулі розрахувати ймовірність випадкового вбивства та ймовірність випадкового поранення людини.

Використовуючи можливості імітаційного моделювання, запропоновано встановлювати показники ймовірності ураження людини в залежності від кутів пострілу, які дозволять обгрунтувати обмеження під час стрільби по БпЛА із стрілецької зброї.

На основі запропонованого методичного підходу, визначені напрямки подальших досліджень щодо визначення ймовірності випадкового влучення кулі в людину під час стрільби зі штатної зброї калібрів від 5,45 мм та 12,7 мм по повітряним цілям типу БпЛА, які дозволять вжити заходи щодо забезпечення мінімального рівня загроз цивільному населенню.
\end{abstract}

\footnotetext{
АНаціональний університет оборони України імені Івана Черняховського, м. Київ, Україна, д.т.н., професор, завідувач кафедри логістики Повітряних Сил інституту авіації та протиповітряної оборони, e-mail: mirnenkovi@gmail.com, ORCID: 0000-0002-7484-1035

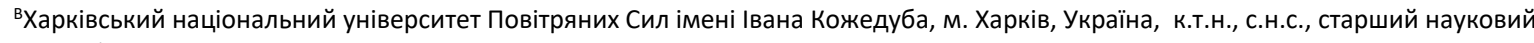
співробітник науково-дослідного відділу наукового центру, e-mail: novichenko_s@ukr.net, ORCID: 0000-0001-7043-446X

“Харківський національний університет Повітряних Сил імені Івана Кожедуба, м. Харків, Україна, к.т.н., старший науковий співробітник науково-дослідного відділу наукового центру, e-mail: doskaleks@gmail.com, ORCID: 0000-0002-9874-8716

DНаціональний університет оборони України імені Івана Черняховського, м. Київ, Україна, к.т.н., начальник науково-дослідного відділу інституту авіації та протиповітряної оборони, e-mail: pavel.openko@ukr.net, ORCID: 0000-0001-7777-5101

ЕНаціональний університет оборони України імені Івана Черняховського, м. Київ, Україна, к.т.н., старший викладач кафедри логістики Повітряних Сил інституту авіації та протиповітряної оборони, e-mail: savram1977@gmail.com, ORCID: 0000-0003-1358-1185
} 
Ключові слова: загроза цивільному населенню, ймовірність випадкового влучення кулі в людину, застосування стрілецької зброї.

\section{Постановка проблеми}

Досвід ведення бойових дій на сході України свідчить, що для боротьби з БпЛА, які діють на малих та гранично малих висотах разом 3 зенітними ракетними комплексами (ЗРК), переносними ЗРК та зенітними установками застосовується і вогонь зі штатної стрілецької зброї $[1,2]$.

Повітряні цілі типу БпЛА за своїм характером і можливостями маневру мають суттєві особливості порівняно з рухомими наземними цілями, що призводять до необхідності вироблення особливих правил стрільби по них із стрілецької зброї. Незначні розміри БпЛА та безперервна і швидка зміна його положення в просторі викликає суттєві труднощі в наведенні стрілецької зброї та може привести до промаху. В результаті виникає загроза життю і здоров'ю цивільного населення, що знаходиться в межах досяжності куль, яка полягає в можливості ураження або травмування людей внаслідок випадкового влучення кулі. Дана обставина у відповідності до $[3,4] \epsilon$ неприпустимою.

В зв'язку з цим виникає необхідність забезпечення певного рівня безпеки цивільного населення у разі застосування стрілецької зброї по БпЛА.

\section{Аналіз останніх досліджень та публікацій}

Для забезпечення необхідного рівня безпеки цивільного населення необхідно виробити єдиний підхід щодо оцінювання рівня загроз населенню у разі застосування стрілецької зброї по повітряних цілях, у тому числі і по БпЛА та провести доопрацювання (уточнення) документів, які регламентують застосування стрілецької зброї.

Зокрема, в [5] систематизовані та викладені правила стрільби, загальні для всіх видів стрілецької зброї, у тому числі по рухомих та повітряних цілях. Однак, питання безпеки цивільному населенню при виконанні стрільб по повітряних цілях в [5] не розглядаються.

В [6] наведено основні відомості з балістики теорії стрільби зі стрілецької зброї та розглянуті способи визначення імовірності попадання в ціль, що представляє собою нерухому ростову, або грудну мішень. Оцінювання випадкового влучення кулі в цивільну людину при стрільбі по мішені в [6] не проводилося. Крім того, в існуючих настановах [6] та правила стрільби [5] відсутні обмеження щодо безпечного використання стрілецької зброї при стрільбі по повітряних цілях.

В [7] приводяться данні щодо сил і моментів, діючих в польоті на снаряд (ракету). Пропонуються способи дослідження траєкторій та оцінюється вплив зовнішніх факторів на стійкість польоту, розсіювання траєкторій та похибок стрільби.

В [8] розглянуто питання оцінки показників ефективності стрільби по одиночній і груповій цілях та наведенні відповідні розрахункові співвідношення. Показники, які характеризують рівень загрози випадкового влучення кулі в людину при стрільбі по БпЛА в [8] не розглядаються.

Таким чином, проведений аналіз свідчить, що завдання оцінювання рівня загроз цивільному населенню у разі застосування стрілецької зброї по БпЛА $є$ невирішеним, а тема статті актуальною.

\section{Постановка завдання}

Вплив внутрішніх та зовнішніх факторів в ході локальних війн та збройних конфліктів, спрямований на обрання методів ведення збройної боротьби вимагає від військових керівників усіх ступенів постійного забезпечення безпеки цивільного населення в 
зоні ведення бойових дій. Саме тому виникає необхідність наукового обгрунтування визначення показника оцінки рівня загроз цивільному населенню при застосуванні стрілецької зброї по повітряним цілям (в тому числі БпЛА).

Отже, наукове завдання полягає в подальшому удосконаленні методичного підходу прогнозування рівня загроз цивільному населенню у разі застосування стрілецької зброї по повітряних цілях (в тому числі БпЛА).

Метою статті $\epsilon$ розробка науковометодичного апарату прогнозування рівня загроз цивільному населенню у разі застосування стрілецької зброї по повітряних цілях (в тому числі БпЛА), що базується на основі теорії ймовірностей.

\section{Виклад основного матеріалу}

Однією 3 особливостей стрільби зі стрілецької зброї по БпЛА $€$ низька частка потрапляння куль в такі цілі. В цих умовах кулі, особливо ті, що не влучили в ціль, падаючи можуть завдати шкоди життю i здоров'ю людей в межах досяжності.

У якості показника, яким можна оцінити рівень загроз цивільному населенню при використанні стрілецької зброї по БпЛА використаємо імовірності випадкового влучення кулі в людину. При цьому, в залежності від кінетичної енергії кулі, можна виділити імовірність випадкового вбивства і випадкового поранення людини.

Імовірність випадкового влучення кулі в людину, що розташована на певній відстані від стрілка при стрільбі короткою чергою по БпЛА може бути розрахована за співвідношенням:

$$
P_{B}(d)=P_{\beta}(d) \cdot P_{D}(d),
$$

де $P_{\beta}(d)$ - імовірність виконання пострілу в інтервалі азимутів у напрямку на людину, що розташована на дальності $d(M)$;
$P_{D}(d)$ - імовірність виконання пострілу в інтервалі кутів місця, які забезпечують влучення кулі у людину, що розташована на дальності $d(M)$, при умові стрільби в ії напрямку.

Малорозмірні БпЛА можуть з'являться 3 будь-якого напрямку відносно вогневих груп, тому цілком можливо вважати азимут стрільби відносно людини випадковою величиною 3 рівномірною щільністю розподілу в межах від $0^{\circ}$ до $360^{\circ}$. Звідси, імовірність виконання пострілу в інтервалі азимутів в напрямку на людину можна визначити наступним чином (мал. 1):

$$
P_{\beta}(d)=\frac{\Delta \beta}{2 \cdot \pi}=\frac{L}{2 \cdot \pi \cdot d},
$$

де $\Delta \beta=\frac{L}{d}$ - величина інтервалу азимутів стрільби в напрямку на людину в залежності від дальності до неї (виражене в радіанах);

$L$ - середній розмір людини в горизонтальній площині (м).

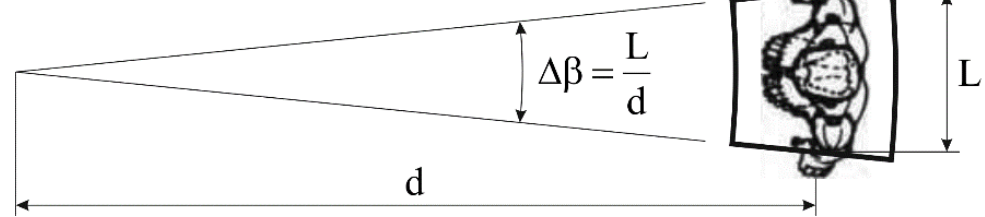

Мал. 1 - Схема визначення ймовірності виконання пострілу в інтервалі азимутів у напрямку людини

Раптовість застосування (виявлення) малорозмірних БпЛА призводить до того, що стрілок може виконувати стрільбу по цілі при будь-яких кутах місця (в межах від $0^{\circ}$ до 90), тому можна вважати кут місця стрільби випадковою величиною 3 рівномірною щільністю розподілу. Звідси, імовірність виконання пострілу в інтервалі кутів місця, 
які забезпечують влучення кулі у людину при умові стрільби в їі напрямку можна визначити наступним чином (мал. 2):

$$
P_{D}(d)=\frac{2}{\pi} \cdot \Delta \varepsilon(d)
$$

де $\Delta \varepsilon(d)$ - величина інтервалу кутів місця стрільби, при яких забезпечується влучення кулі в людину при умові стрільби в їі напрямку за азимутом (в радіанах).

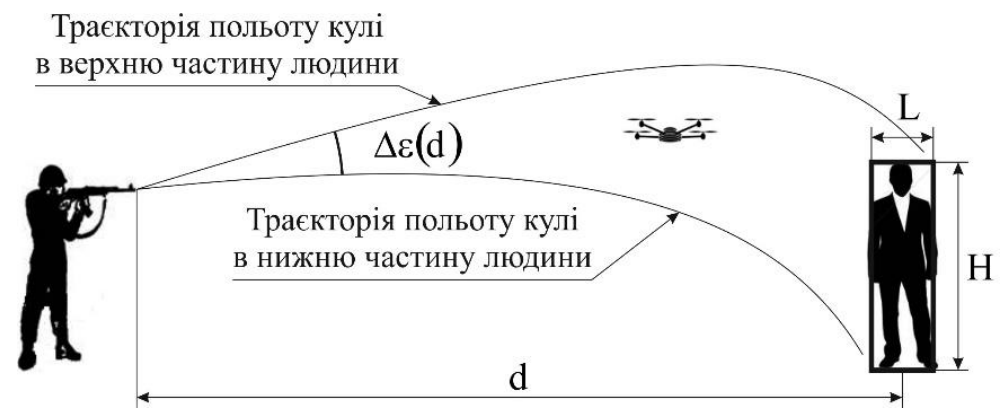

Мал. 2 - Схема визначення ймовірності виконання пострілу в інтервалі кутів місця, які забезпечують влучення кулі у людину

Величину інтервалу кутів місця стрільби, при яких забезпечується влучення кулі в людину $\Delta \varepsilon(d)$ визначити досить складно 3 огляду на те, що його значення залежить від траєкторій польоту кулі і дальності до людини. Більш того, дія сили тяжіння на кулю призводить до існування двох значень кута місця, при яких куля летить на певну дальність (окрім випадку стрільби на максимальну дальність).

Тому, враховуючи рівномірний закон розподілу кута місця стрільби, визначення імовірності $P_{D}(d)$ доцільно провести рахунковим методом, за співвідношенням:

$$
P_{D}(d)=\frac{N \varepsilon_{B}(d)}{N \varepsilon},
$$

де $N \varepsilon_{B}(d)$ - кількість кутів місця стрільби, при яких забезпечується влучення кулі в людину, що знаходиться на дальності $d(\mathrm{M})$;

$$
N \varepsilon=\operatorname{int}\left(\frac{\pi}{2 \cdot \Delta \varepsilon}\right) \text { - загальна кількість кутів }
$$

місця стрільби в межах від $0^{0}$ до $90^{\circ}$;

$\operatorname{int}(x)$ - функція округлення числа $x$ до меншого цілого числа;

$\Delta \varepsilon$ - інтервал розділення сектору стрільби у вертикальній площині;

Тобто, для визначення імовірності (3) необхідно: розділити сектор стрільби у вертикальній площині від $0^{0}$ до $90^{\circ}$ на однакові інтервали розміром $\Delta \varepsilon$;

для кожного кута місця стрільби $\varepsilon_{k}=k \cdot \Delta \varepsilon$, де $k=\overline{1, N \varepsilon}$ визначити факт влучення кулі у людину, що розташована на дальності $d$;

розрахувати кількість кутів місця стрільби, при яких забезпечується влучення кулі в людину $N \varepsilon_{B}(d)$.

Визначення факту влучення кулі в людину, що розташована на дальності $d$ при стрільбі 3 кутом місця $\varepsilon_{k}$ в ії напрямку за азимутом здійснюється шляхом:

побудови траєкторії польоту кулі з заданим кутом місця стрільби;

перевірки факту перетину ії 3 прямокутником, розміром $L \times H$ (мал. 2), що знаходиться на дальності $d$ i апроксимує форму людини.

Оскільки розміри кулі набагато менші шляху, який вона долає у польоті, то ії рух можна розглядати як рух матеріальної точки (центру мас) $\vec{P}(t)=\{X(t), Y(t)\}$ у часі, який, як правило, задається табличним способом за результатами дослідних стрільб при нормальних умовах їх виконання.

Зважаючи на обмеження умов виконання дослідних стрільб (кут місця стрільби міняється в діапазоні лише декількох градусів) виникає необхідність побудови математичної моделі 
руху кулі у вертикальній площині при заданому куті місця стрільби, з прийняттям наступних спрощень (мал. 3):

зміна руху кулі у просторі здійснюється під дією сили тяжіння $\vec{F}_{T}$ і сили опору повітря $\vec{F}_{C}$, що в сумі становлять результуючу силу $\vec{F}$;

вектор сили опору повітря приложений до центру мас кулі і направлений протилежно вектору їі швидкості $\vec{V}$;

враховуючи незначні дальності і висоти польоту куль стрілецької зброї, земну поверхню доцільно представити площиною, силу тяжіння вважати направленою протилежно нормалі цій площині і такою, що не залежить від висоти польоту кулі.

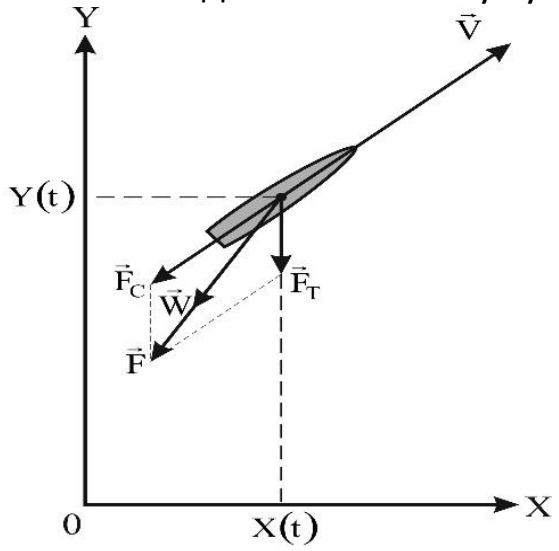

Мал. 3 - Сили, що діють на кулю в польоті

В загальному випадку, траєкторію польоту кулі можна отримати шляхом інтегрування її швидкості (з врахуванням початкового положення) наступним чином:

$$
\left\{\begin{array}{l}
X(t)=X(0)+\int_{0}^{t} V_{X}(\tau) \cdot d \tau \\
Y(t)=Y(0)+\int_{0}^{t} V_{Y}(\tau) \cdot d \tau,
\end{array}\right.
$$

де $X(0), Y(0)$ - початкові координати (координати пострілу) в прямокутній правосторонній системі координат (далі - в стартовій системі координат);

$V_{X}(t), V_{Y}(t)$ - складові вектору швидкості кулі $\vec{V}(t)=\left\{V_{X}(t), V_{Y}(t)\right\}$ в момент часу $t$.

Відповідно складові вектору швидкості кулі змінюються в часі наступним чином:

$$
\left\{\begin{array}{l}
V_{X}(t)=V_{X}(0)+\int_{0}^{t} W_{X}(\tau) \cdot d \tau ; \\
V_{Y}(t)=V_{Y}(0)+\int_{0}^{t} W_{Y}(\tau) \cdot d \tau,
\end{array}\right.
$$

де $V_{X}(0), V_{Y}(0)$ - початкові складові вектору швидкості кулі в момент пострілу (виходу кулі з каналу стволу);

$W_{X}(t), \quad W_{Y}(t) \quad$ - складові вектору прискорення кулі $\vec{W}(t)=\left\{W_{X}(t), W_{Y}(t)\right\} \quad$ в момент часу $t$.

Початкові складові вектору швидкості кулі в момент пострілу визначаються наступним чином:

$$
\left\{\begin{array}{l}
V_{X}(0)=V(0) \cdot \cos \left(\varepsilon_{k}\right) \\
V_{Y}(0)=V(0) \cdot \sin \left(\varepsilon_{k}\right)
\end{array}\right.
$$

де $V(0)$ - модуль вектору швидкості кулі в момент пострілу (виходу кулі з каналу стволу).

Враховуючи прийняті спрощення, складові вектору прискорення кулі можна отримати наступним чином:

$$
\left\{\begin{array}{l}
W_{X}(t)=\left[V_{X}(t) \cdot C\left(\sqrt{V_{X}(t)^{2}+V_{Y}(t)^{2}}\right) \times\right. \\
\left.\times \rho_{0} \cdot e^{-\eta \cdot Y(t)} \cdot \sqrt{V_{X}(t)^{2}+V_{Y}(t)^{2}} \cdot S_{m}\right] / 2 \cdot m ; \\
W_{Y}(t)=\left(\left[V_{Y}(t) \cdot C\left(\sqrt{V_{X}(t)^{2}+V_{Y}(t)^{2}}\right) \times\right.\right. \\
\left.\left.\times \rho_{0} \cdot e^{-\eta \cdot Y(t)} \cdot \sqrt{V_{X}(t)^{2}+V_{Y}(t)^{2}} \cdot S_{m}\right] / 2 \cdot m\right)-g,
\end{array}\right.
$$

де $C(V)$ - безрозмірний аеродинамічний коефіцієнт опору повітря кулі в залежності від швидкості $V$;

$\rho_{0}$ - густина повітря на поверхні Землі;

$\eta$ - показник зменшення густини повітря з висотою;

$S_{m}$ - найбільша поперечна площа кулі відносно напрямку руху;

$m$ - маса кулі.

Функція $C(V)$, як правило, має табличний вид і формується за результатами дослідних стрільб у визначених умовах їх проведення.

Для вирішення рівняння (6) може бути використані чисельні методи інтегрування, наприклад, метод трапеції [9].

Траєкторію польоту кулі необхідно визначати у певних відліках часу, які розташовані через рівні проміжки:

$$
t_{i}=i \cdot \Delta t,
$$

де $i=\overline{1, N_{T}}$ - номер відліку часу;

$N_{T}$ - кількість відліків часу польоту кулі; 
$\Delta t-$ проміжок між відліками часу.

Кількість відліків часу польоту кулі $N_{T}$ визначається до моменту часу падіння кулі на земну поверхню.

Оскільки у визначенні прискорення кулі (8) використовуються компоненти вектору швидкості і положення кулі, що для того ж відліку часу $€$ невідомими величинами, то при визначенні прискорення кулі у певний момент часу пропонується замінити їх прогнозними значеннями наступним чином:

$$
\left\{\begin{array}{l}
W_{X}\left(t_{i}\right)=\left[\hat{V}_{X}\left(t_{i}\right) \cdot C\left(\hat{V}\left(t_{i}\right)\right) \times\right. \\
\left.\times \rho_{0} \cdot e^{-\eta \cdot \hat{Y}\left(t_{i}\right)} \cdot \hat{V}\left(t_{i}\right) \cdot S_{m}\right] / 2 \cdot m \\
W_{Y}\left(t_{i}\right)=\left(\left[\hat{V}_{Y}\left(t_{i}\right) \cdot C\left(\hat{V}\left(t_{i}\right)\right) \times\right.\right. \\
\left.\left.\times \rho_{0} \cdot e^{-\eta \cdot \hat{Y}\left(t_{i}\right)} \cdot \hat{V}\left(t_{i}\right) \cdot S_{m}\right] / 2 \cdot m\right)-\mathrm{g},
\end{array}\right.
$$

де $\hat{V}\left(t_{i}\right)=\sqrt{\hat{V}_{X}\left(t_{i}\right)^{2}+\hat{V}_{Y}\left(t_{i}\right)^{2}}$ - прогнозне значення модулю вектору швидкості кулі в момент часу $t_{i}$;

$\hat{Y}\left(t_{i}\right)$ - прогнозне значення висоти польоту кулі в момент часу $t_{i}$.

Прогнозне значення компонентів вектору швидкості кулі в момент часу $t_{i}$ можна визначити приймаючи гіпотезу про рівномірну їх зміну наступним чином:

$$
\left\{\begin{array}{l}
\hat{V}_{X}\left(t_{i}\right)=2 \cdot V_{X}\left(t_{i-1}\right)-V_{X}\left(t_{i-2}\right) ; \\
\hat{V}_{Y}\left(t_{i}\right)=2 \cdot V_{Y}\left(t_{i-1}\right)-V_{Y}\left(t_{i-2}\right),
\end{array}\right.
$$

де $V_{X}\left(t_{i-1}\right), V_{Y}\left(t_{i-1}\right)$ - компоненти вектору швидкості кулі в момент часу $t_{i-1}$;

$V_{X}\left(t_{i-2}\right), V_{Y}\left(t_{i-2}\right)$ - компоненти вектору швидкості кулі в момент часу $t_{i-2}$;

$$
\begin{aligned}
& V_{X}(-\Delta t)=V_{X}(0) ; \\
& V_{Y}(-\Delta t)=V_{Y}(0) .
\end{aligned}
$$

Прогнозне значення висоти польоту кулі в момент часу $t_{i}$, приймаючи гіпотезу про рівномірну її зміну, визначається наступним чином:

$$
\hat{Y}\left(t_{i}\right)=2 \cdot Y\left(t_{i-1}\right)-Y\left(t_{i-2}\right),
$$

де $Y(-\Delta t)=Y(0)$.
Визначивши прискорення кулі у визначений момент часу, можна визначити його швидкість наступним чином:

$$
\left\{\begin{array}{l}
V_{X}\left(t_{i}\right)=V_{X}\left(t_{i-1}\right)+\frac{W_{X}\left(t_{i-1}\right)+W_{X}\left(t_{i}\right)}{2} \cdot \Delta t ; \\
V_{Y}\left(t_{i}\right)=V_{Y}\left(t_{i-1}\right)+\frac{W_{Y}\left(t_{i-1}\right)+W_{Y}\left(t_{i}\right)}{2} \cdot \Delta t
\end{array}\right.
$$

де $W_{X}(0)=W_{Y}(0)=0$ - початкове прискорення кулі вважається нульовим.

Положення кулі у визначений момент часу в стартовій системі координат визначається наступним чином:

$$
\left\{\begin{array}{l}
X\left(t_{i}\right)=X\left(t_{i-1}\right)+\frac{V_{X}\left(t_{i-1}\right)+V_{X}\left(t_{i}\right)}{2} \cdot \Delta t ; \\
Y\left(t_{i}\right)=Y\left(t_{i-1}\right)+\frac{V_{Y}\left(t_{i-1}\right)+V_{Y}\left(t_{i}\right)}{2} \cdot \Delta t .
\end{array}\right.
$$

Перевірка умови влучення, тобто факту перетину траєкторії (14) з прямокутником, розміром $L \times H$, що знаходиться на дальності $d$ здійснюється шляхом послідовної перевірки виконання трьох наступних умов:

$$
\begin{aligned}
Y\left(t_{i-1}\right) & \leq H \text { або } Y\left(t_{i}\right) \leq H \\
X\left(t_{i}\right) & \geq d-\frac{L}{2} \text { та } X\left(t_{i-1}\right) \leq d+\frac{L}{2}, \\
Y_{б л} & \leq H \text { або } Y_{\text {дал }} \leq H .
\end{aligned}
$$

Висоти перетину ліній початку і кінця прямокутника $Y_{б л}$ та $Y_{\text {дал }}$ з траєкторією визначаються наступним чином:

$$
\left\{\begin{array}{l}
Y_{б л}=Y\left(t_{i-1}\right)+\frac{d-\frac{L}{2}-X\left(t_{i-1}\right)}{X\left(t_{i}\right)-X\left(t_{i-1}\right)} \cdot\left(Y\left(t_{i}\right)-Y\left(t_{i-1}\right)\right) ; \\
\left.Y_{\text {дал }}=Y\left(t_{i-1}\right)+\frac{d+\frac{L}{2}-X\left(t_{i-1}\right)}{X\left(t_{i}\right)-X\left(t_{i-1}\right)} \cdot\left(Y\left(t_{i}\right)-Y\left(t_{i-1}\right)\right)\right) .
\end{array}\right.
$$

Цю умову влучення можна доповнити перевіркою на перевищення певної швидкості кулі в момент влучення, для оцінки імовірності випадкового вбивства чи поранення людини, наступним чином:

$$
\sqrt{V_{X}\left(t_{i}\right)^{2}+V_{Y}\left(t_{i}\right)^{2}} \geq V_{\text {гр }}
$$

де $V_{z p}$ - граничне значення швидкості кулі для нанесення ураження, яке розглядається. 
Тобто умова влучення вважається виконана тоді, коли виконані усі зазначені умови ((15) - (17), (19)).

Таким чином, визначення імовірності випадкового влучення кулі в людину, що розташована на певній відстані від стрілка при стрільбі короткою чергою по БпЛА можна здійснити за алгоритмом, який наведений на мал. 4.

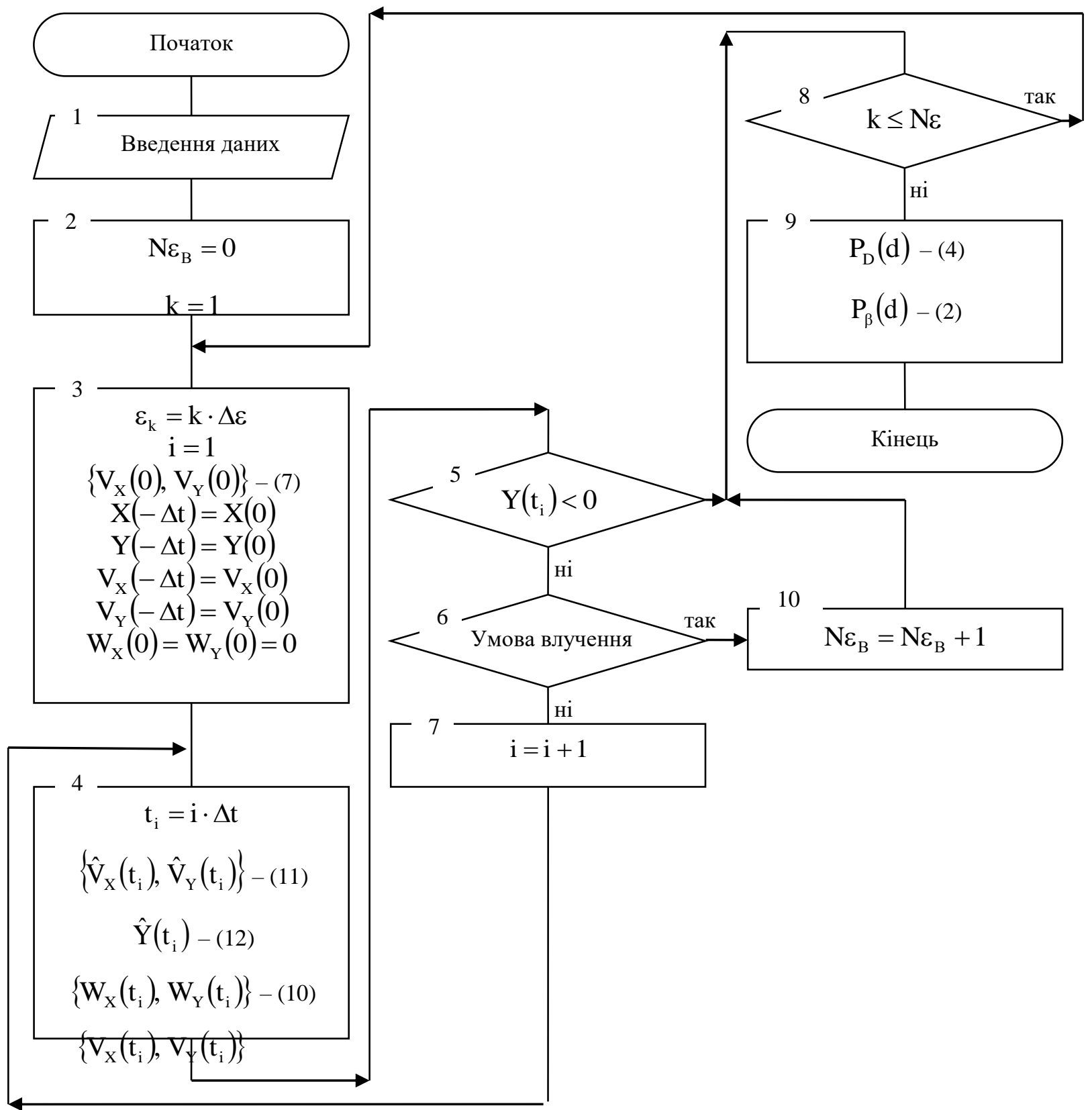

Мал. 4 - Алгоритм визначення ймовірності випадкового влучення кулі в людину, що розташована на певній відстані від стрілка при стрільбі короткою чергою по БпЛА

В блоці 1 алгоритму (мал. 4) здійснюється введення вихідних даних, до яких входять:

$\rho_{0}$ - густина повітря на поверхні Землі, $\mathrm{Kr} / \mathrm{M}^{3}$; $\eta$ - показник зменшення густини повітря 3 висотою;

$\Delta \varepsilon$ - інтервал розділення сектору стрільби у вертикальній площині, рад; 
$\Delta t$ - проміжок між відліками часу при побудові траєкторій, с;

$X(0), \quad Y(0)$ - початкові координати (координати пострілу) в стартовій системі координат, м;

$V(0)$ - модуль вектору швидкості кулі в момент пострілу (виходу кулі з каналу стволу), $\mathrm{M} / \mathrm{C}$;

$C(V)$ - безрозмірний аеродинамічний коефіцієнт опору повітря кулі в залежності від швидкості $V$, табличні значення;

$S_{m}$ - найбільша поперечна площа кулі відносно напрямку руху, M² $^{2}$

$m$ - маса кулі, кг;

$d$ - дальність до людини, м;

$L, H$ - геометричні розміри людини, м;

$V_{\text {гp }}$ - граничне значення швидкості кулі для

нанесення ураження, яке розглядається, $\mathrm{M} / \mathrm{c}$.

Кінцевий результат (блок 9) відображає ступінь ураження людини відповідно до введеного граничного значення швидкості кулі $V_{\text {гр }}$, і може бути: ймовірністю випадкового вбивства людини. При цьому граничне значення швидкості кулі вводиться відповідно до вбивчої сили людини кулею визначеного калібру;

ймовірністю випадкового поранення людини. При цьому граничне значення швидкості кулі може бути значно менше, ніж у попередньому випадку.

Використовуючи розроблений алгоритм (мал. 4), в подальшому будуть отримані результати оцінки загроз життю і здоров'ю людини, яка знаходиться в межах досяжності куль зі сталевим осердям калібрів (від 5,45 до 12,7) мм, при стрільбі короткою чергою по БпЛА одним стрільцем із стрілецькою зброєю.

Таким чином, після отримання результатів задачу розрахунку рівня загроз цивільному населенню при застосуванні стрілецької зброї по БпЛА можна буде вважати вирішеною.

Отримані результати рекомендовано використовувати для обгрунтування зон (секторів) безпеки при стрільбі зі стрілецької зброї по повітряним цілям та уточнення відповідних розділів правил стрільби.

\section{Висновки}

Запропоновано у якості показника оцінки рівня загроз цивільному населенню при застосуванні стрілецької зброї по БпЛА використовувати ймовірність випадкового влучення кулі в людину.

Розроблено методичний підхід до оцінювання рівня загроз цивільному населенню, який ґрунтується на імітаційному моделюванні процесу польоту кулі у вертикальній площині. Основою методичного підходу $є$ алгоритм визначення ймовірності випадкового влучення кулі в людину, який дозволяє, в залежності від кінетичної енергії кулі, розрахувати ймовірність випадкового вбивства та ймовірність випадкового поранення людини.

На основі запропонованого методичного підходу, напрямком подальших досліджень запропоновано визначення ймовірності випадкового влучення кулі в людину під час стрільби зі штатної зброї калібрів від 5,45 мм до 12,7 мм по повітряним цілям типу БпЛА, які дозволять вжити заходи щодо забезпечення мінімального рівня загроз цивільному населенню.

\section{Список використаних джерел}

1. ОБСЄ знову втратила безпілотник над окупованим Донбасом // Українська правда від 15.08.2019. URL: https://www.pravda. com.ua/news/2019/08/15/7223597.

2. Ганкевич Р. Бійці АТО збили над лінією розмежування безпілотник.zaxid.net. від 09.02.2017.
[Електронний pecypc]. URL: https://zaxid.net/biytsi_ato_

zbili_nadliniyeyu_rozmezhuvannya_rosiyskiy_ bezpilotnik_n1417461.

3. Інструкція про порядок виконання норм міжнародного гуманітарного права у Збройних Силах України. Затверджена 
наказом Міністра оборони України № 164 від 23.03.2017. URL: https://zakon.rada.gov.ua /laws/show/z070417.

4. Інструкція із заходів безпеки при поводженні зі зброєю. Затверджена наказом наказом Міністра внутрішніх справ України № 70 від 01.02.2016. URL:https://zakon.rada.gov.ua/ laws/show/z0250-16/stru.

5. Правила стрельбы из стрелкового оружия и гранатометов. Москва: Воениздат, 1972. $136 \mathrm{c}$.

6. Наставление по стрелковому делу. Основы стрельбы из стрелкового оружия. Москва:
Воениздат, 1970. 177 с.

7. Дмитриевский А.А. Внешняя баллистика. Москва: Машиностроение, 1972. 322 с.

8. Средства поражения и боеприпасы: Учебник / А.В. Бабкин, В.А. Валденов, Е.Ф. Грязнов, [и др.]. Москва: Изд-во МПТУ им. Н.Э. Баумана, 2008. 984 с.

9. Демидович Б. П., Марон И.А.Основы вычислительной математики. Москва: Наука, 1966. 664 с.

10. Таблицы стрельбы по наземным целям из стрелкового оружия калибров 5,45 и 7,62 Мм. ТС/ГРАУ №61. Изд. второе. Дополненное. Москва: Воениздат, 1977. 265 с.

\title{
Методический подход к оценке уровня угроз гражданскому населению в случае применения стрелкового оружия по беспилотным летательным аппаратам
}

\author{
Владимир Мирненко ; Сергей Новиченко ; Александр Доска'; \\ Павел Опенько ${ }^{D}$; Александр Авраменко ${ }^{\mathrm{E}}$ \\ АНациональный университет обороны Украины имени Ивана Черняховского, д.т.н., профессор, заведующий кафедры логистики \\ Воздушных Сил института авиации и противовоздушной обороны, e-mail: mirnenkovi@gmail.com

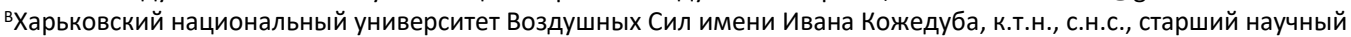 \\ сотрудник научно-исследовательского отдела, e-mail: novichenko_s@ukr.net \\ сХарьковский национальный университет Воздушных Сил имени Ивана Кожедуба, к.т.н., старший научный \\ сотрудник научно-исследовательского отдела, e-mail: doskaleks@gmail.com \\ рНациональный университет обороны Украины имени Ивана Черняховского, к.т.н., начальник научно-исследовательского \\ отдела института авиации и противовоздушной обороны, e-mail: pavel.openko@ukr.net \\ ЕНациональный университет обороны Украины имени Ивана Черняховского, к.т.н., старший преподаватель кафедры \\ логистики Воздушных Сил института авиации и противовоздушной обороны, e-mail: savram1977@gmail.com
}

\begin{abstract}
Аннотация
Результаты исследований, опубликовано в статье, будут полезны для руководителей воинских коллективов всех уровней, которые отвечают за обеспечение безопасности гражданского населения в ходе применения вооружения. В статье рассматриваются методический подход к оценке уровня угроз гражданскому населению в случае применения стрелкового оружия по беспилотным летательным аппаратам (БПЛА). Проанализированы существующие документы, регламентирующие применение стрелкового оружия, установлено, что вопросы безопасности гражданского населения при выполнении стрельб по воздушным целям в них не рассматривалось, что позволило сформулировать нерешенную научную задачу, которая заключается в формировании методического подхода к оценке уровня угроз гражданскому населению в случае применения стрелкового оружия по БПЛА. Предложено научное обоснование определения вероятности случайного попадания пули в человека, расположенного на определенном расстоянии от стрелка при стрельбе по БПЛА. В качестве показателя оценки уровня угроз гражданскому населению при применении стрелкового оружия по БПЛА обосновано использование показателя “вероятность случайного попадания пули в человека". Приведенный методический подход к оценке угроз гражданскому населению, основанной на имитационном моделировании процесса полета пули в вертикальной плоскости, основой которого является алгоритм
\end{abstract}


определения вероятности случайного попадания пули в человека, который позволяет, в зависимости от кинетической энергии пули, рассчитать вероятность случайного убийства и вероятность случайного ранения человека. Представленные расчетные соотношения, позволяющие в зависимости от кинетической энергии пули рассчитать вероятность случайного убийства и вероятность случайного ранения человека.

Используя возможности имитационного моделирования, предложено устанавливать показатели вероятности поражения человека в зависимости от углов выстрела, которые позволят обосновать ограничения при стрельбе по БПЛА из стрелкового оружия.

На основе предложенного методического подхода, определены направления дальнейших исследований по определению вероятности случайного попадания пули в человека во время стрельбы из штатного оружия калибров от 5,45 мм и 12,7 мм по воздушным целям типа БПлА, которые позволят принять меры по обеспечению минимального уровня угроз гражданскому населению.

Ключевые слова: угроза гражданскому населению, вероятность случайного попадания пули в человека, применение стрелкового оружия.

\title{
Methodical approach to the assessment of the level of threats to civilians in the case of the use of small arms on unmanned aerial vehicles
}

\author{
Volodymyr Mirnenko'; Sergii Novichenko ${ }^{B}$; Oleksandr Doska'; \\ Pavlo Open'ko ${ }^{\mathrm{D}}$; Oleksandr Avramenko ${ }^{\mathrm{E}}$ \\ AThe National Defence University of Ukraine named after Ivan Cherniakhovskyi, Doctor of Technical Sciences, Professor, \\ Head of the Chair of the Air Force Logistics Department of the Aviation and Air Defence Institute, e-mail: mirnenkovi@gmail.com \\ BIvan Kozhedub Kharkiv National Air Force University, Ph.D. in Technical Science, Senior Reseacher, Senior Reseacher of the \\ Scientific-research Department, e-mail: novichenko_s@ukr.net \\ 'Ivan Kozhedub Kharkiv National Air Force University, Ph.D. in Technical Science, Senior Reseacher of the Scientific-research \\ Department, e-mail: doskaleks@gmail.com \\ DThe National Defence University of Ukraine named after Ivan Cherniakhovskyi, Ph.D. in Technical Science, Head of the \\ Scientific-research Department of the Aviation and Air Defence Institute, e-mail: pavel.openko@ukr.net \\ EThe National Defence University of Ukraine named after Ivan Cherniakhovskyi, Ph.D. in Technical Science, Senior lecturer of the \\ Air Force Logistics Department of the Aviation and Air Defence Institute, e-mail: savram1977@gmail.com
}

\begin{abstract}
The results of the research published in the article will be useful for leaders of all levels of military personnel responsible for ensuring the safety of civilians in the use of weapons. The article discusses a methodical approach to assessing the level of threats to civilians in the case of unmanned aerial vehicles (UAVs). Analyzed existing documents regulating the use of small arms, it was found that the issue of safety of civilians in the firing of air targets they were not considered, which allowed to determine the unresolved scientific problem, which is to form a methodological approach to assessing the level of threats to civilians in the case of use small arms on UAV. The scientific substantiation of the probability of accidental hit of a bullet into a person, located at a certain distance from the arrow when firing on UAV, is offered. As an indicator of assessing the level of threats to civilians in the use of small arms under the UAV, the use of the indicator "the probability of accidentally hitting a bullet into a person" is justified. The method of estimation of threats to the civilian population which is based on imitation modeling of process of flight of a ball in a vertical plane, the basis of which is the algorithm of determination of probability of accidental hit of a ball into a person, which allows, depending on kinetic energy of a ball, to calculate probability of accidental and accidental probability. The calculated ratios are presented, which allow, depending on the kinetic energy of the ball, to calculate the probability of accidental killing and the probability of accidentally injuring a person.
\end{abstract}


Using the capabilities of simulation it is proposed to set the probability of human damage, depending on the angles of the shot, which will justify the restrictions during firing of UAVs with small arms.

On the basis of the proposed methodological approach, the directions of further researches on determination of the probability of accidental hit of a bullet in a person during firing of regular weapons of calibers from $5,45 \mathrm{~mm}$ and $12,7 \mathrm{~mm}$ on air targets of the UAV type will be determined, which will allow to take measures to ensure a minimum level of threats civilians.

Keywords: threat to civilian population, probability of accidental hit of a bullet in a person, use of small arms.

\section{References}

1. OSCE znovu vtratila bezpilotnik nad okupovanim Donbasom // Ukrayinska pravda vid 15.08.2019. URL:https://www.pravda. com.ua/news/2019/08/15/7223597

2. Gankevich R. Biytsi ATO zbili nad linieyu rozmezhuvannya rosiyskiy bezpilotnik / R. Gankevich // zaxid.net. vid 09.02.2017. URL: https://zaxid.net/biytsi_ato_zbili_nad liniyeyu_rozmezhuvannya_rosiyskiy_bezpilotn ik_n1417461.

3. Instruktslya pro poryadok vikonannya norm mlzhnarodnogo guman Itarnogo prava u Zbroinykh Sylah Ukrainy. Zatverdzhena nakazom Ministra oborony Ukrainy № 164 vid 23.03.2017. URL:https://zakon.rada.gov.ua /laws/show/z0704-17.

4. Instruktsiya iz zahodiv bezpeki pri povodzhenni zi zbroeyu. Zatverdzhena nakazom Ministravnutrishnih sprav Ukrainy № 70 vid 01.02.2016. URL: https://zakon.rada. gov.ua/laws/show/z0250$16 /$ stru.
5. Pravila strelbyi iz strelkovogo oruzhiya i granatometov. Moscow: Voenizdat, 1972. $136 \mathrm{~s}$.

6. Nastavlenie po strelkovomu delu. Osnovyi strelbyi iz strelkovogo oruzhiya. Moscow: Voenizdat, 1970. $177 \mathrm{~s}$.

7. Dmitrievskiy A.A. Vneshnyaya ballistika.Moscow: Mashinostroenie, 1972. $322 \mathrm{~s}$.

8. Sredstva porazheniya i boepripasyi: Uchebnik / A.V. Babkin, V.A. Valdenov, E.F. Gryaznov, [i dr.]. Moscow: Izd-vo MGTU im. N.E. Baumana, 2008. $984 \mathrm{~s}$.

9. Demidovich B.P.,Maron I.A.Osnovyi vyichislitelnoy matematiki.Moscow: Nauka, 1966. $664 \mathrm{~s}$.

10. Tablitsyi strelbyi po nazemnyim tselyam iz strelkovogo oruzhiya kalibrov 5,45 i 7,62 mm. TS/GRAU №61. Moscow: Voenizdat, 1977. $265 \mathrm{~s}$. 